\section{P-593 経尿道的手術におけるクリニカルパスの導} $\lambda$

\section{医真会八尾総合病院 泌尿器科 ${ }^{11}$}

岩井哲郎1) 柏井浩希1) 黑岡公雄1)

日的】クリニカルパスの導入の利点としては医療の標準化だけで なく、インフォームドコンセントの充実、医療スタッフの業務統 一などがあげられる。また、在院日数の短縮や医療コストの削減 に有用とされている。経尿道的手術に执いてクリ二カルパスを導 人しその結果を報告する。【対象と方法】对象は1999年4月より 10月までにTUR-p症例32例ならびにTUR-bt症例24例である。パス の内容ついては、手術前後の投莧、処置手術後の安静度や食事な どを経時的具体的に記載した。パス導入前後での在院日数ならび に医療コストを比較検討した。【結果】TUR-p症例においてパス導 入前での平均術後在院日数は 8.5 日でパス導入後は7.3日と 1.2 日短 縮した。また医療コストはパス導入前で35.0万円でパス導入後は 30.2 万人 4.8 万円削減された。TUR-b症例に拀いてパス導入前で の平均術後在院日数は 6.0 日でパス導入後は 5.8 日と 0.2 日短縮した。 また医療コストはパス導入前で 36.0 万円でパス導入後は 28.3 万と 6.7 万削減された。経尿道的手術に拀いてクリニカルパスを導入 するは在院日数の短縮ならびに医療コスト削隇に有効と考える。 pass TUR clinical

\section{P-594}

前立腺肥大症に対する剥離TURPの臨床評 価

\begin{abstract}
日本医科大学付属多摩永山病院 泌尿器科 ${ }^{11}$

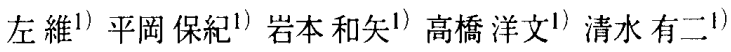

沼沢和夫 ${ }^{1)}$ (伊藤 博 ${ }^{1)}$ 千賀 康弘 1 ) 藤田和明1)

【目的】前立腺肥大症に対する剥離TURPの有用性について臨床拉 よび病理学的検討を行った。方法】1998年度当院で前立腺肥大疗 と診断され剥離TURPを施行した101例を対象とした。年龄は57〜 86 (平均68.83才) であった。尿流動態学検査、国際前立腺症状ス コア、推定前立腺体積、PSA及び病理学的事項につき検討した。 【結果】IPSSの術前後値は17.24から9.20へ、QOLの術前後俌は4.75 から1.81へ、Qmaxの術前後值は9.60から18.69 $\mathrm{ml} / \mathrm{s}$ へ、Qaveの術前後

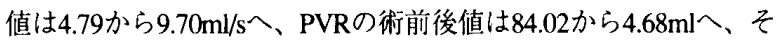
れぞれ有意に改善が認められた。推定前立腺体積は術前 $32.11 \mathrm{~g}$ 術 後 3 ケ月で11.21 $\mathrm{g}$ に、PSA值は術前6.83ng/mlから術後 3 ケ月日で $0.88 \mathrm{ng} / \mathrm{ml}$ となった。偶発癌 6 例が検出された。その内、術前 3 回 針生検で㓌性 1 例を含む 3 例は針生検陰性であった（年齡75〜86 平均79.33才)。この 6 例の癌分布は内腺限局のみ 3 例、内外腺輌 方陽性 3 例であった。【総括】剥離TURPは前立腺肥大症の治療お よび偶発癌の検出に有用な方法であることが示唆された。
\end{abstract}

前立腺肥大症 剥噰TURP 偶発病

\section{P-595 膀胱頸部硬化症に対するTUI-P（経尿道的 前立腺切除術）の検討}

\section{耳原総合 泌尿器科 1 .}

蛹宜田 正志 ${ }^{\prime \prime}$ 畑中祐二1）宮崎隆夫1) 永井信夫1)

【目的】当科にて施行した膀胱頸部硬化症に対するTUI-Pの臨床成 績について検討した。【対象と方法】1989年4月から1999年3月まで の期間で88例の膀胱頸部硬化症症例に対してTUI-Pを施行した。8 8 例中以前に内尿道切開術などの経尿道的手術を施行されていた 10 例、明らかな神経因性膀胱を有する9例、術後経過観察が不能で あった1例を除いた68例の原発性膀胱頸部硬化症を対象とした。 TUI-Pの術式は、ナイフ型電極で膀胱頸部の5時および7時の位置で 膀胱三角部から精丘の遠位端までを切開した。切開の梁さは膀腅 頸部では輪状線維、前立腺部では被膜が露出するまでとした。さ らにわれわれは6時の位置の前立腺をループ電極で切除した。検 討項目は、自覚症状の改善率、術前、術後1ヶ月目、3力月目の最 大尿流率、平均尿流率、手術時間、合併症、膀胱頸部硬化症の再 発についても検討した。また、切除した膀胱頸部組織の病理診断 も検討し、治療効果と病理診断との関係についても考察した。 【結果】平均手術時間は16.2分。自覚症状の改善率は $89.1 \%$ 。最大 氺流滦、平均尿流率は術前と比較して1力月目、3力月目ともに有 意に改善していた。術後4例で尿道狭窄を認めた。術後膀胱頸部 硬化症の再発は1例もなかった。病理診断と治療効果との間には 明らかな関係は見いだせなかった。

脖胱頚部硬化症 TUI-P

\section{$P-596$ 小さい前立腺肥大症に対する TURーPの 検即}

\section{水戸済生会総合病院 泌尿器科1}

鈴木 正彦1) 常樂晃 ${ }^{1}$ 野口良輔1)

【目的】小さい前立腺肥大症に対する $\mathrm{T} U \mathrm{R}-\mathrm{P}$ の効果を検討し た。【対象】1992年から1998年までに当施設にて前立腺肥大症に対 してTUR－Pを施行された症例の中で、腹部エコー検査による 前立腺推定重量が30g以下かつ切除腺腫重量が $15 \mathrm{~g}$ 以下の32症例を 対象とした。平均年齢は67.7歳で、平均前立腺推定重量は $18.5 \mathrm{~g}$ 、 平均切除腺腫重量は $10.4 \mathrm{~g}$ であった。治療効果は T U R - P 前後の 最大尿流量率にて判定した。【結果】評価订能であった 28 症例の

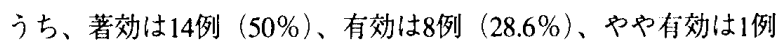
(3.6\%)、不変は5例 $(17.9 \%)$ であった。合併症としては後出血が 4例（12.5\%）にみられ、うち3例は内視镜による止血術を要した。 被膜穿孔は2例 $(6.3 \%)$ にみられた。術後膀脳預部狭窄は4例 (12.5\%) にみられ、うち 3 例は経尿道的膀胱澒部切開を施行され た。【結論】一般に小さい前立腺肥大症に対して T UR-Pを施 行した場合、術後膀胱䅡部狭窄の発生頻度が高いと言われている が、我々の調査では $12.5 \%$ こてれまでの報告と同程度であった。 しかしながら、術後の患者のQＯLの改善などを考えると施行す る価值は十分にあると考えられた。

小さい前立腺肥大症 T U R - P 術後膀胱頚部狭窄 